\begin{tabular}{|l|l|}
\hline 2. To: (Receiving Organization) & $\begin{array}{l}\text { 3. From: Coriginating Organization) } \\
\text { Equipment Engineering }\end{array}$ \\
DISTRIBUTION & $\begin{array}{l}\text { 6. Design Authority/ Design Agent/Cog. } \\
\text { Engr.: } \\
\text { 5. Proj./Prog./Dept./Div.: }\end{array}$ \\
TWRS/E\&S/EQP ENG & Scaief III \\
\hline
\end{tabular}

8. Originator Remarks:

This EDT is for release of HNF-3661.
11A. Design Baseline Document? [x] Yes [] No

\begin{tabular}{|}
$\begin{array}{c}\text { 4. Related EDT No.: } \\
624012\end{array}$ \\
N/A \\
$\begin{array}{c}\text { 7. Purchase Order No.: } \\
\text { N/A }\end{array}$ \\
$\begin{array}{c}\text { 9. Equip./Component No.: } \\
\text { 10. System/Bldg./Facility: }\end{array}$ \\
N/A \\
\hline $\begin{array}{c}\text { 12. Major Assm. Dwg. No.: } \\
\text { N/A }\end{array}$ \\
13. Permit/Permit Application No.: \\
14. Required Response Date:
\end{tabular}

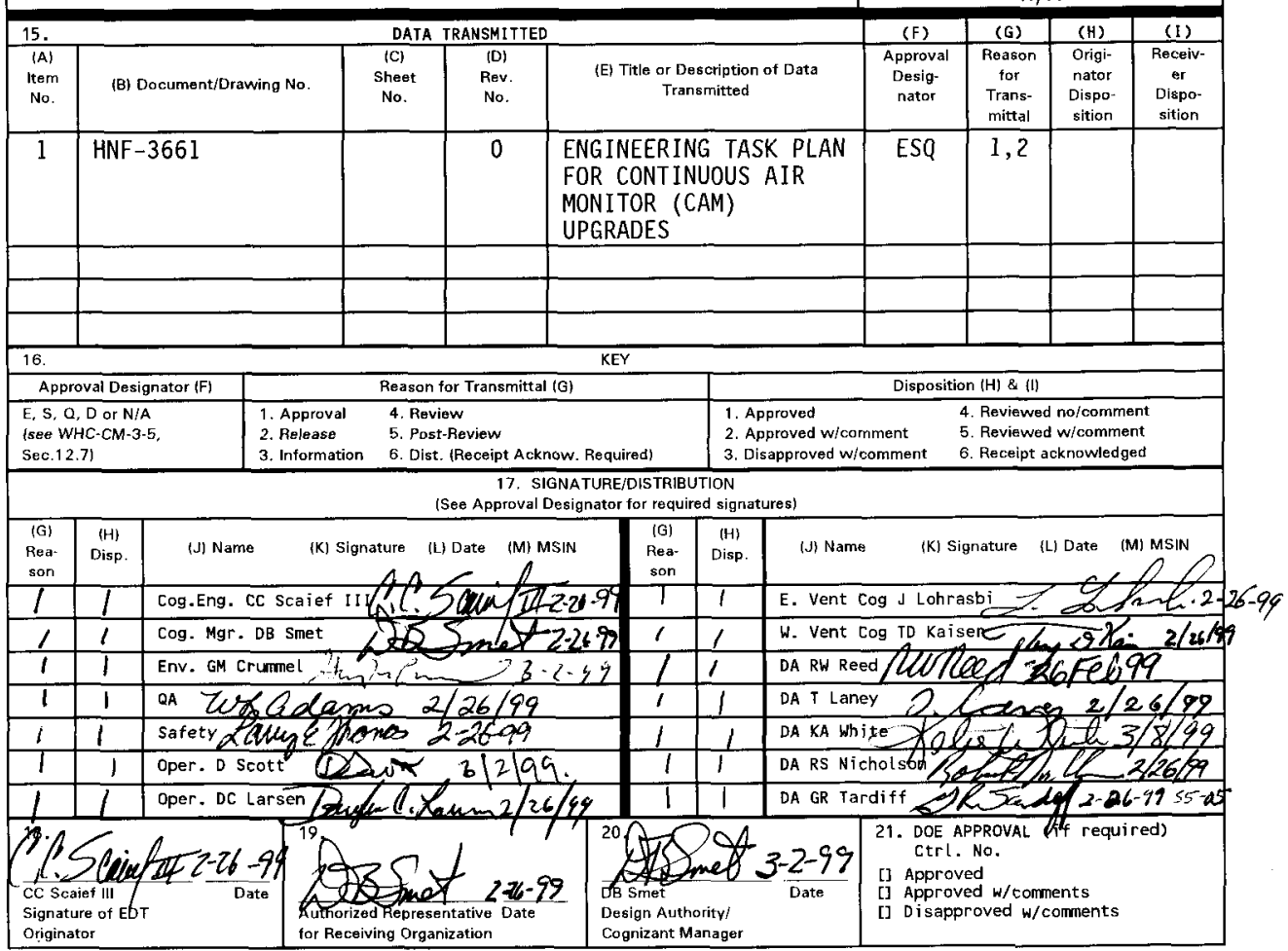

$8 D-7400-172-2(05 / 96) \quad$ GEF097 


\title{
ENGINEERING TASK PLAN FOR CONTINUOUS AIR MONITOR (CAM) UPGRADES
}

\author{
CC Scaief III
}

Lockheed Mart in Hanford Corporation, Richland, WA 99352

U.S. Department of Energy Contract DE-AC06-96RL13200

$\begin{array}{llll}\text { EDT/ECN: } & \text { EDT-624013 } & \text { UC: } 510 \\ \text { Org Code: } & 74700 & \text { Charge Code: } & 106612 \\ \text { B\&R Code: } & \text { EW3120071 } & \text { Total Pages: } 12\end{array}$

Key Words: Air Monitoring, CAM, upgrade, leak detection, annulus, requirements

Abstract: This document provides a plan for replacement of existing Continuous Air Monitors (CAM) in the tank annuli and K1 and K2 exhausters for selected Tank Farm facilities. Requirements are included.

TRADEMARK DISCLAIMER. Reference herein to any specific commercial product, process, or service by trade name, trademark, manufacturer, or otherwise, does not necessarily constitute or imply its endorsement, recommendation, or favoring by the United States Government or any agency thereof or its contractors or subcontractors.

Printed in the United States of America. To obtain copies of this document, contact: Document Control Services, P.O. Box 950, Mailstop H6-08, Richland WA 99352, Phone (50́9) 372-2420; Fax (509) 376-4989.
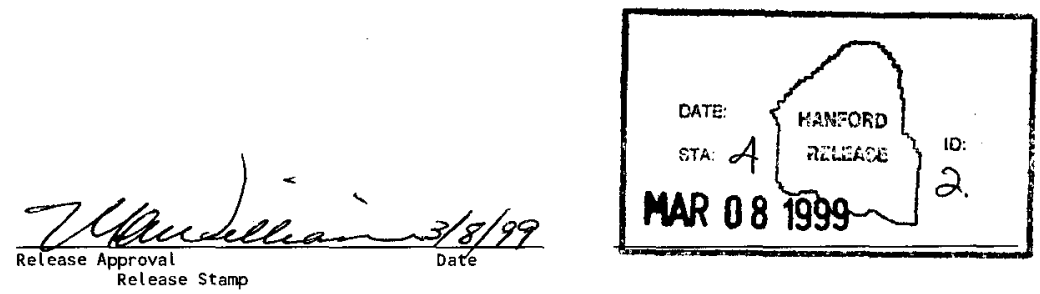


\section{$H N F-3661$}

Rev. 0

ENGINEERING TASK PLAN FOR CONTINUOUS AIR MONITOR (CAM) UPGRADES TABLE OF CONTENTS

1.0 INTRODUCTION . . . . . . . . . . . . . . . . . . . . 1

2.0 WORK SCOPE ....................... . . 1

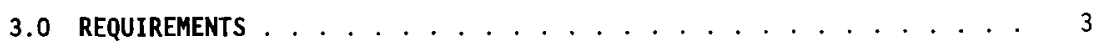

4.0 TASK DESCRIPTIONS . . . . . . . . . . . . . . . . . 6

5.0 COST AND SCHEDULE $\ldots \ldots \ldots \ldots$

6.0 REFERENCES . . . . . . . . . . . . . . . . . . . . . 8

7.0 APPENDIX: ACCEPTANCE FOR BENEFICIAL USE ............ 10 
HNF-366l, Rev. 0

\subsection{INTRODUCTION}

Continuous Air Monitors (CAM) are utilized for annulus leak detection as well as for particulate emission monitoring of the primary (K1) and annulus (K2) ventilation exhaust systems. This Engineering Task Plan provides guidance, responsibilities and requirements for replacement of existing CAMs at selected Tank Farm facilities. The replacement of CAMs at AN Farm is described by Engineering Task Plan HNF-2871. The AN Farm upgrade was initiated in Fiscal Year 1998 and information on AN is included in this task plan. The addition of a computer for readout was not included in HNF-2871. As such, this task plan supersedes HNF-2871.

The installations at the facilities selected for replacement currently use Eberl ine model AMS-3A and $3 A-1$ beta CAMs. The AMS-3A units have integral detector and electronics in one cabinet. The detector has a lead shield (pig) and the total weight of the unit is 160 lbs. The AMS-3A-1 units have the detector and electronics separated (split pig). The detector is also quite heavy but is somewhat easier to handle. Typically the CAMs are located in metal enclosures and are on shelves. In most cases they are above shoulder height. Removal of the AMS-3A for calibration and maintenance is difficult and poses a lifting hazard to the craftsperson.

Some of the CAMs have been modified to accommodate different types of recorders and some have the bell and strobe removed for mounting external to the equipment cabinet. These modifications prevent interchange with other locations. This task will replace the AMS-3A and 3A-1 CAMS with AMS-4s that represent current technology. The AMS-4s incorporate microprocessors as we 1 as an integral flow meter for sample flow. This allows measurement of concentration using a sliding time window as well as total accumulated activity on the filter. The background subtraction is more sophisticated and the alarm choices are greater. The main processing unit with display is separate from the remote sampling head. The AMS-4 uses a gas proportional detector that generates an output pulse with height (voltage) proportional to the energy of the incident gamma ray or particle. This allows the circuitry to more effectively discriminate background gamma rays from beta particles. As such, minimal shielding is used and the sampling head only weighs approximately $10 \mathrm{lbs}$. The replacement units will remain unmodified from the factory allowing interchange with other locations using AMS-4s.

\subsection{WORK SCOPE}

This activity includes replacement of CAMs and in some locations the existing recorders will be removed. In such cases, an industrial PC will be installed and the CAMs will be monitored using the RS-485 host computer connection on each. Locations such as $A Y / A Z$ that have no existing recorders will not be connected to a $\mathrm{PC}$ unless existing spare cable can be located. Locations with only one CAM (e. g. 204-AR) will also not receive a PC. This can be changed during design provided there is some technical or safety (e. g. ALARA) reason. 
HNF-3661, Rev. 0

At all other locations that have existing active recorders, the recorders will be retained and connected to the AMS -4 . The AMS 4 uses a five decade $\log$ scale for the analog output and the AMS-3 uses a four decade log scale. Since the AMS-3 and AMS-4 use millivolt and volt outputs respectively, an external voltage converter will be required. The voltage converter will be scaled to provide only four decades from the AMS-4 to the recorder thus avoiding the design and procurement of new chart paper. The following table provides a summary of systems to be upgraded in order of priority.

\begin{tabular}{|c|c|c|c|c|c|}
\hline SYSTEM & LOCATION & TRR & NESHAP STATUS & SAFETY & $\begin{array}{l}\text { REMOTE } \\
\text { LOGGING }\end{array}$ \\
\hline $296-A-29$ & AN Farm Primary K1 & \multirow[b]{3}{*}{ 240.N67 } & Non-designated & SC & $\mathrm{PC}$ in $\mathrm{AN}-271$ \\
\hline $296-A-30$ & AN Farm AnnuTus K2 & & Non-designated & GS & $\mathrm{PC}$ in $\mathrm{AN}-271$ \\
\hline $\begin{array}{l}\text { AN Farm } \\
\text { Annuli }\end{array}$ & AN 101-107 & & $\mathrm{N} / \mathrm{A}$ & SC & $\mathrm{PC}$ in $\mathrm{AN}-271$ \\
\hline $296-A-40$ & AP Farm Primary Kl & \multirow[b]{3}{*}{ 240.P67 } & Non-designated & SC & $P C$ in $A P-271$ \\
\hline $296-A-41$ & AP Farm Annulus K2 & & Non-designated & GS & $\mathrm{PC}$ in $\mathrm{AP}-271$ \\
\hline $\begin{array}{l}\text { AP Farm } \\
\text { Annuli }\end{array}$ & AP 101-108 & & $\mathrm{N} / \mathrm{A}$ & SC & $\mathrm{PC}$ in $\mathrm{AP}-271$ \\
\hline $296-P-23$ & SY Farm Primary K1 & \multirow{4}{*}{$240 . Y 67$} & Non-designated & SC & $P C$ in $242-S$ \\
\hline $296-P-28$ & SY Farm Kl Backup & & Non-designated & SC & $\begin{array}{l}\text { None } \\
\text { Existing }\end{array}$ \\
\hline $296-P-22$ & SY Farm AnnuTus K2 & & Non-designated & $\overline{G S}$ & PC in 242-S \\
\hline $\begin{array}{l}\text { SY Farm } \\
\text { Annuli }\end{array}$ & SY 101-103 & & $\mathrm{N} / \mathrm{A}$ & $\mathrm{SC}$ & PC in 242-S \\
\hline $\begin{array}{l}\text { AY Farm } \\
\text { Annul } j\end{array}$ & AY $101-102$ & \multirow[b]{2}{*}{240.267} & $N / A$ & SC & $\begin{array}{l}\text { None } \\
\text { Existing }\end{array}$ \\
\hline $\begin{array}{l}\text { AZ Farm } \\
\text { Annuli }\end{array}$ & AZ 101-102 & & $N / A$ & SC & $\begin{array}{l}\text { None } \\
\text { Existing }\end{array}$ \\
\hline $296-S-15$ & SX Farm Primary & 240.567 & Non-designated & SC & $\begin{array}{l}\text { None } \\
\text { (inactive) }\end{array}$ \\
\hline $296-A-26$ & $\begin{array}{l}\text { 204-AR Unloading } \\
\text { Facility }\end{array}$ & $240 . R 67$ & Non-designated & SC & $\begin{array}{l}\text { Recorder in } \\
\text { Control Room }\end{array}$ \\
\hline $296-S-18$ & $\begin{array}{l}\text { 242-S Evaporator } \\
\text { Building }\end{array}$ & $240 . E 67$ & Non-des ignated & GS & $\begin{array}{l}\text { Recorder in } \\
\text { Control Room }\end{array}$ \\
\hline $296-C-05$ & 244-CR Vault & $240 . F 67$ & Designated & SC & TBD \\
\hline $296-\mathrm{T}-17$ & $\begin{array}{l}\text { 242-T Evaporator } \\
\text { Facility }\end{array}$ & $240 . T 67$ & Non-designated & GS & TBD \\
\hline
\end{tabular}

At AN Farm, the existing $K 1$ and $K 2$ cabinets will be removed and replaced with cabinets and equipment that conform to the generic stack monitor design. Existing generic cabinets are available that were never operational. These cabinets will be moved to AN Farm and installed with the new AMS-4. 
HNF-3661, Rev. 0

The task also includes the generation of any required calibration and maintenance procedures and associated data sheets. Acceptance testing and final functional testing will be performed. Where applicable, the design change will not affect the operation of the existing CAM exhauster interlock for the associated ventilation system.

\subsection{REQUIREMENTS}

The primary tank leak detection systems (annulus CAMs) are Safety Class for the flammable gas deflagration and the surface leak resulting in a pool accidents. The CAMs associated with primary DST, DCRT and SST ventilation is Safety Class for the spray leak accident (PHMC, 1997b and 1997d). Both the leak detection CAMs and the primary ventilation CAMs have Technical Safety Requirements (TSR) imposed to ensure their proper functioning. The applicable LCOs are 3.1.4 (ventilation) and 3.2.6 (annulus). See PHMC, 1997c.

The primary ventilation CAM is also Safety Significant for the HEPA filter failure accident for protection of the onsite worker. The K2 CAMs and the 242-S and 242-T Evaporator CAMs have no BI0 safety function.

\section{Safety Function}

The ventilation CAM is OPERABLE if it detects $\geq 10,000 \mathrm{cpm}$ and inter locks (shuts down) the primary ventilation exhaust fans. The accident analysis for the spray leak does not specify a setpoint and the 10,000 cpm has been selected as a maximum based on normal operating practice as described in Bases 3.1.4 (PHMC, 1997c). A leak detection CAM is OPERABLE when it is capable of detecting radiation levels above the setpoint and alarming. No setpoint is specified in the LCO or Bases for the leak detector CAM, however, a maximum setpoint of $10,000 \mathrm{cpm}$ has also been selected in practice. A review of HNFSD-WM-RD-057 (PHMC, 1997a) for the annulus CAMs resulted in no additional requirements or definitions of OPERABLE.

The AMS-4 is an Alternate Replacement Item as defined in HNF-IP-0842, Volume IV, Section 3.11 (PHMC, 1997g). The AMS-4 has a different form and fit from the AMS-3A, however, it is functionally superior. It allows alarming on both net beta count $(10,000 \mathrm{cpm})$ as wel1 as on specific activity. The net beta count represents the accumulated counts on the filter and is equivalent to the AMS-3 cpm. The background subtraction is more sophisticated. These features ensure a faster response to alarm on an upset condition. As such, the safety function is fully met by use of the AMS -4 .

\section{Environmental Monitoring}

The ventilation exhaust systems provide discharge of potentially contaminated vapor to the atmosphere. The requirement for continuous monitoring for environmental emission compliance is based on the potential for offsite exposure. For stacks with a potential of $\leq 0.1 \mathrm{mrem} / \mathrm{yr}$, there are no continuous monitoring requirements as specified in WHC-CM-7-5, Section 2.5.3.2 (WHC, 1997). A1l exhaust systems with the exception of 244-CR have been determined to be non-designated (less than $0.1 \mathrm{mrem} / \mathrm{yr}$ potential emissions) 
HNF-3661, Rev. 0

per HNF-SD-WM-EMP-031 (PHMC, 1997f). As such, there are no environmental monitoring requirements imposed on these CAMs.

The 296-C-05 System (244-CR) is a designated stack and is required to be compliant with the National Emission Standards for Hazardous Air Pollutants (NESHAP) as specified in the 40 Series Code of Federal Regulations (40CFR), Part 61, Subpart H. This system does not present7y meet the requirements but is scheduled for upgrades by Project $W-420$ that will make it compliant. No special Environmental Monitoring requirements are imposed for the replacement of the CAM. From an Environmental Monitoring perspective the AMS-4 is considered superior to the AMS-3.

Fail Safe Design

The Bases of the applicable LCOS (3.1.4 and 3.2.6) as well as HNF-SD-WM-RD-057 (PHMC, 1997a) state that CAM malfunctions are normally detected and alarmed. Like the AMS-3A, the AMS-4 has failure detection for low count rate as well as expanded failure detection for sample flow limits.

Environmental Conditions

The design ambient temperature range for equipment (PHMC, 1998) shall be as follows:

$\begin{array}{lr}\text { Outdoor } & -25^{\circ} \mathrm{F} \text { to } 115^{\circ} \mathrm{F} \\ \text { Buildings } & 50^{\circ} \mathrm{F} \text { to } 95^{\circ} \mathrm{F} \\ \text { Sample Stream } & 40^{\circ} \mathrm{F} \text { to } 115^{\circ} \mathrm{F}\end{array}$

The sample stream temperature is based on a search of the Surveillance Analysis Computer System (SACS) temperature data base for AN, AP and AW farms. The highest temperature recorded was $94^{\circ} \mathrm{F}$ at tank AN-104 in September of 1998 . Twenty degrees were added for the heaters. The low temperature is somewhat arbitrary but conservatively high. The large ratio of vapor space volume to flow rate combined with tank or annulus heating precludes approaching very low temperatures.

The manufacturer of the CAM (Eberline) specifies a slightly higher operating temperature $\left(122^{\circ} \mathrm{F}\right)$ for the AMS-4 than for the AMS $-3 A\left(120^{\circ} \mathrm{F}\right)$. The 7 ower operating temperature of the AMS-4 is specified as $32^{\circ} \mathrm{F}$ as opposed to $20^{\circ} \mathrm{F}$ for the AMS-3A. The AMS-4 has been determined to exhibit a much broader temperature range during performance testing (PNNL, 1996). Three AMS-4 CAMs were tested against requirements of the American National Standards Institute (ANSI, 1980 and 1989). The tests included verifying performance to specification over the temperature range of $-20^{\circ} \mathrm{C}$ to $60^{\circ} \mathrm{C}\left(-4^{\circ} \mathrm{F}\right.$ to $\left.140^{\circ} \mathrm{F}\right)$. The AMS-4s demonstrated compliance over the specified range with the exception of a small incompliance with the flow meter on one unit. The flow meter reading does not affect the net beta count alarm parameter and therefore has no effect on the safety function. The existing cabinets have both fans for cooling as well as heaters for cold temperatures. These environmental controls are expected to be adequate even for high temperature periods with incident solar insolation. 
HNF-3661, Rev. 0

Natural Phenomena Hazards

As directed in the referenced letter (Raymond, 1998) DOE 6430.1A design criteria (DOE, 1989) need only be applied to the specific SSC design attribute(s) that are used to perform or maintain the safety class safety function(s) identified in the TWRS authorization basis. Since this is not a new SSC and there is no change in the principal operating parameters, the BIO controls continue to apply. There is no BIO defined safety function for the CAMs associated with Natural Phenomena Hazards (NPH). The design requirements in HNF-PR0-097 (PHMC, 1997e) for NPH are therefore applied based on Performance Category (PC) 1. For design loads this is equivalent to Uniform Building Code (UBC) requirements. As such, no NPH qualification will be performed.

Single Failure Criterion and Redundancy

DOE 6430.1A, Section 1300-3.3 (DOE 1989) requires the following with regard to single failures:

The design shall ensure that a single failure does not result in the loss of capability of a safety class system to accomplish its required safety functions.

Since the CAM is an Alternate Replacement Item, it has the same function as the component it is replacing. This activity is not considered a "modification" as defined by HNF-PR0-517 (PHMC, 1997h) since it does not result in a change in principal operating parameters or impact the safety function. The design for replacement wi1l not address single failures except to ensure the replacement component will not introduce new failures. The AMS$3 A$, has failure detection capability only for detector or high voltage failure (low count rate). The AMS -4 has more extensive failure alarms (Fail Safe Design above) than the AMS-3A. As such the AMS-4 is considered an acceptable Alternate Replacement Item from the standpoint of single failure criterion.

Loss of Power

DOE 6430.1A, Section 1660-99.0.1 (DOE 1989) requires that:

For safety class items that require electric power to perform their safety functions, the design shall provide safety class emergency electric power systems ...

The AMS-4 is designed to alarm (fail) on loss of power. The resulting alarm requires entering into an LCO Action. Loss of power does not therefore impact the safety function since the Action places the facility in a safe condition (terminate transfers) or requires the use of backup surveillance (annulus conductivity detectors).

Ignition Control Sets

The TWRS Technical Safety Requirements (PHMC, 1997c) Administrative Control 5.10 imposes ignition source controls on equipment in Ex-Tank and Dome Intrusive areas. There are no controls on the annulus space. There are also no controls on the main ventilation train downstream of the first mixing point 
HNF-3661, Rev. 0

so long as the ventilation system is operating (non-intrusive area). When the ventilation system is not operating, downstream of the first mixing point is an Ex-Tank area. There are TSR controls (monitoring) on restarting the ventilation system after it has been down for an excessive time period.

The evaporators and the 204-AR unloading facility are not subject to ignition source controls. The 244-CR Vault has ignition source controls imposed within each tank (TK-001, -002 and -003) dome space only during waste disturbing operations. The ventilation system mixes air from the vault as well as the three tanks and is therefore considered to be downstream of the first mixing point. As such, there are no ignition source controls on the CAM sample stream.

The AMS -4 was evaluated by the Flammable Gas Equipment Advisory Board (FGEAB) without the use of the internal flow sensor and found to be equivalent to ISC2 requirements (FGEAB-97-029, Rev 4). The flow sensor was not evaluated since it was not being used in the particular application reviewed. Approval for the flow sensor is not required since none of the installations are subject to ignition source control requirements as discussed above.

\section{Other Requirements}

The existing alarms and annunciation functions will be retained at all locations. There are no requirements for continuous recording imposed by the BIO or by NESHAP. As discussed in the task description, however, any existing active recording will be retained or replaced by computer monitoring with trending files saved to disk.

\subsection{TASK DESCRIPTIONS}

The following main tasks have been identified in support of this upgrade. Each task is described and responsible organizations and/or personnel have been identified.

Cognizant Engineering and Design Authority

The Cognizant Engineer responsible for the overall upgrade activity is C. C. Scaief III of TWRS Equipment Engineering. D. B. Smet of Equipment Engineering will be the responsible Cognizant Manager. The ventilation Cognizant Engineers for Single She 11 and Double Shell Tanks will provide the facility approvals. Each facility Design Authority will approve all media as required and as applicable.

Design Activities

The installation design will consist of ECNs to existing drawings. The ECNs and as-built drawings will be prepared by Fluor Daniel Northwest or other qualified design agent but will be released by Lockheed Martin Hanford. The responsible Cognizant Engineer for design will be C. C. Scaief III of Equipment Engineering. Design verification will be required and the method will be by formal design review for those systems that are safety class. Change ECNs not affecting the safety function may use other design 
HNF-3661, Rev. 0

verification methods subject to approval by the Design Authority. A USQ screening of the design will also be required. The screening will be prepared by the Cognizant Engineer. The existing Certified Vendor Information (CVI) file number 19183 provides information on the AMS-4 and no new CVI file will be created.

Plant Forces Work Review

A Plant Forces Work Review will be performed to determine whether installation activities will be by Plant Forces or Construction Forces. The Production Support organization will be responsible for preparing the work review and obtaining resolution.

Work Packaqe Preparation

The work package for fabrication, procurement and installation will be prepared by the Production Support organization. Procurement of the AMS-4 CAMs will include Commercial Grade Item (CGI) dedication for safety class. Upon receipt, calibration of each CAM will be performed by Tank Farm Instrument Maintenance. The CGI dedication forms will be prepared by the Cognizant Engineer and approved by the Design Authority.

\section{Procedures}

The functional test procedures for the annulus CAMs and for the K1 CAMs will be revised to reflect any changes necessary as a result of the installation of the AMS-4s. The data sheets will also be revised if necessary. The data sheets for CAM calibration will be provided for the new CAMs. A calibration procedure (6-TF-168) presently exists for the AMS-4 and will not require modification.

Revision of the procedures and data sheets will be performed by Maintenance and Surveillance Engineering and the Procedures Group. This will occur by Procedure Change Authorization (PCA) or by a complete revision depending on the extent of the changes required.

The daily inspections and bi-weekly filter change out for the AMS-4s will be performed using new Procedure TF-HP-005. The monthly inspections and source checks will be performed using new Procedure TF-HP-012.

Testing

Acceptance testing of the CAM modification for the $K 1$ and annulus leak detectors will be by successful completion of the associated functional test procedure. For the general service CAMs (K2 and building) final acceptance of the modification will be by performance of the monthly inspection Procedure TF-HP-012, Maintenance Procedure 6-TF-077 and testing of remote alarms.

Testing of the alarms will be documented in the work package.

Acceptance for Beneficial Use

Appendix A contains an Acceptance for Beneficial Use (ABU) form with deliverable items checked. Responsibilities are also assigned. As required by HNF-IP-0842, Vol IV, 3.12 (PHMC, 1997g), a turnover supporting document will be prepared by the Cognizant Engineer (CC Scaief III) attesting to the 
HNF-3661, Rev. 0

completion of the items on the checklist. Approval of the turnover document will constitute final acceptance.

\subsection{COST AND SCHEDULE}

Costs for the various tasks are contained in the associated TBR packages. There is a commitment to upgrade 25 CAMs by September 30, 1999. This commitment affects the award fee. The CAMs at AN, AP and SY will fulfill this commitment and therefore they are given the highest priority. Construction and final acceptance for these systems is by September 30, 1999. The remaining systems will be designed and installed in the order of priority as presented in Section 2.0.

The schedule for design completion for these systems is provided below. The dates are based on two designers available starting in mid to late February of 1999. The target design completion dates will allow for most construction activities to be completed by the end of the fiscal year.

Design Schedule

\begin{tabular}{lcll} 
System & Number CAMs & & Design Completion \\
\cline { 2 - 2 } AN Farm & 9 & & $1 / 11 / 99$ (actual) \\
AP Farm & 10 & $2 / 17 / 99$ \\
SY Farm & 6 & $4 / 07 / 99$ \\
AY/AZ Farm & 4 & $5 / 14 / 99$ \\
SX Farm & 1 & $6 / 15 / 99$ \\
$204-$ AR & 1 & $6 / 15 / 99$ \\
$242-S$ & 1 & $6 / 15 / 99$ \\
$244-C R$ & 1 & $7 / 15 / 99$ \\
$242-T$ & 1 & $7 / 15 / 99$
\end{tabular}

\subsection{REFERENCES}

ANSI, 1980, Specification and Performance of On-site Instrumentation for Cont inuous7y Monitoring Radioactivity in Effluents, ANSI N42.18, American National Standards Institute, New York.

ANSI, 1989, Performance Specifications for Health Physics Instrumentation Occupational Airborne Radioactivity Monitoring Instrumentation, ANSI N42.17B, American National Standards Institute, New York.

DOE, 1989, Genera7 Design Criteria, DOE 6430.1A, U. S. Department of Energy, Washington, D. C.

PNNL, 1996, Evaluation of the Eberline AMS-3A and AMS-4 Beta Continuous Air Monitors, PNNL-10938, Pacific Northwest National Laboratory, Richland, Washington. 
HNF-366l, Rev. 0

PHMC, 1997a, Tank Waste Remediation System Safety Structures, Systems, and Components: Requirements and Characteristics, HNF-SD-WM-RD-057, Rev. 1, Duke Engineering and Services, Inc., Richland, Washington.

PHMC, 1997b, Tank Waste Remediation System Basis for Interim Operation, HNF-SD-WM-BIO-001, Rev. 1-A, Lockheed Mart in Hanford Company, Richland, Washington.

PHMC, 1997c, Tank Waste Remediation System Technical Safety Requirements, HNF-SD-WM-TSR-006, Rev. D-Q, Lockheed Martin Hanford Company, Richland, Washington.

PHMC, 1997d, Tank Waste Remediation System Facility Safety Equipment List, HNF-SD-WM-SEL-040, Rev. 0-B, Lockheed Mart in Hanford Company, Richland, Washington.

PHMC, 1997e, Engineering Design and Evaluation, HNF-PR0-097, Rev. 0, Fluor Daniel Hanford Company, Richland, Washington.

PHMC, 1997f, Tank Farm Stack NESHAP Designation Determinations, HNF-SD-WM-EMP031, Rev. 3, Lockheed Martin Hanford Company, Richland, Washington.

PHMC, 1997g, Tank Waste Remediation System Administration, HNF-IP-0842, Lockheed Martin Hanford Company, Richland, Washington.

PHMC, 1997h, Safety Analysis Program Glossary, HNF-PR0-517, Fluor Daniel Hanford Company, Richland, Washington.

PHMC, 1998, Intrinsical7y Safe Leak Detector Circuit Design Description, HNFSD-WM-ER-7362, Lockheed Mart in Hanford Company, Richland, Washington.

Raymond, 1998, Letter, R. E. Raymond, LMHC, to M. C. Skriba, FDH, "DOE Order 6430.1A Design Criteria Application for Safety Class Structures, Systems, and Components", LMHC-9852008, dated March 18, 1998.

WHC, 1997, Environmental Compliance, WHC-CM-7-5, Westinghouse Hanford Company, Richland, Washington. 
HNF-3661, Rev. 0

7.0 APPENDIX: ACCEPTANCE FOR BENEFICIAL USE

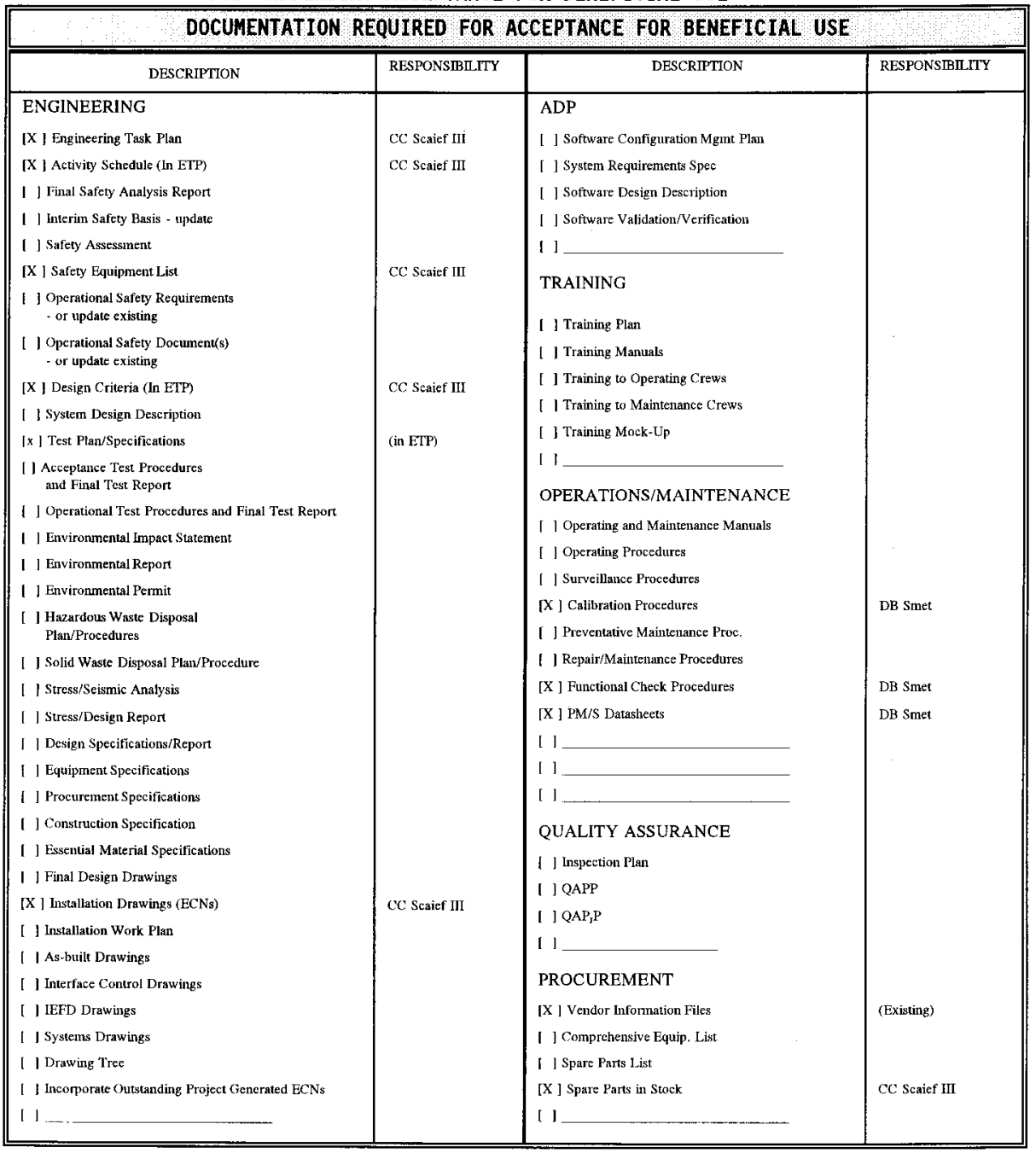




\section{DISTRIBUTION SHEET}

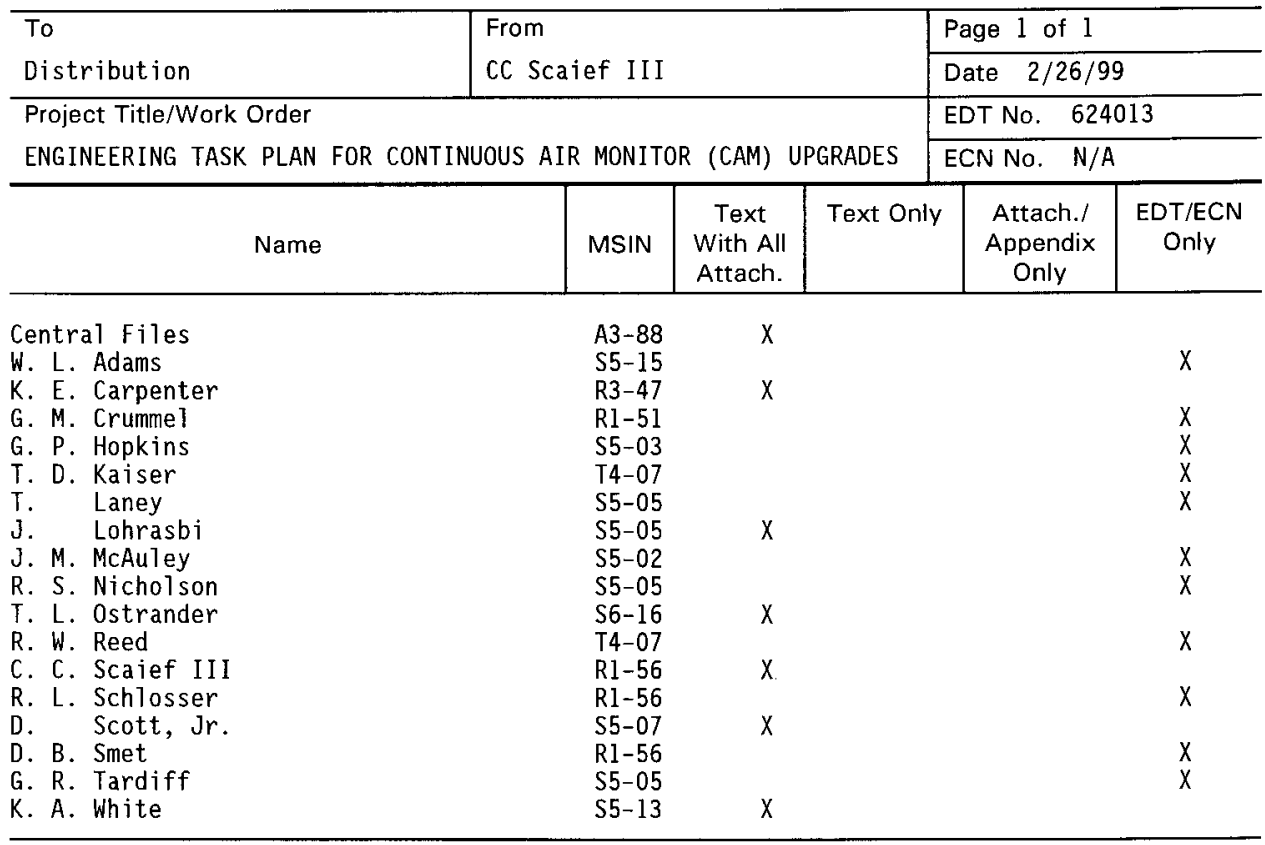

